\title{
A Shrinkage-Reduced Concrete Mix Design for Rehabilitation of Old Dams
}

\author{
Sahar Abd El-Fatah \\ (Lecturer in Construction and building department, High Institute for Engineering \& Technology (HIET)- \\ Bihira, Egypt)
}

\begin{abstract}
A conceptual proposal for retrofitting old dams such as the Old Aswan dam in Egypt is by using a shrinkage-reduced concrete mix. Cracking potential is closely related to the shrinkage rate rather than the shrinkage magnitude. In this paper three types of cement are used, Ordinary Portland cement, Sulphate Resisting cement, and Slag cement. The concrete mixes have three different cement contents with and without admixture. The results show that the increase of cement content tends to increase drying shrinkage. For the three types of cement, the maximum shrinkage of concrete mixes with $350 \mathrm{~kg} / \mathrm{m}^{3}\left(590 \mathrm{Lb} / \mathrm{yd} \mathrm{d}^{3}\right)$ cement content is 35\%-55\% less than the maximum shrinkage of concrete mixes with higher cement contents. For Sulphate Resisting cement concrete mixes, adding $1 \%$ superplasticizer of cement content results in decreasing shrinkage up to $38 \%$ compared with mixes without admixture.
\end{abstract}

Keywords: concrete, old dams, rehabilitation, shrinkage, superplastisizer

\section{Introduction}

Research on health monitoring of structures has received significant attention in recent years. The Old Aswan dam in Egypt is extended across the Nile valley in a straight line at the head of the Aswan cataract where the width of the valley is about $2000 \mathrm{~m}$ (2187.22 yd). It was built in granite masonry set in cement mortar[1]. Nile water which does not contain lime is acidic in reaction and when it finds its way through the pores of bonding mortar between masonry, dissolves the calcium hydroxide formed by the hydration of the cement and carries it out to the surface where it combines with the carbon dioxide in the air to appear as a white efflorescence of calcium carbonate on the wall of sluices [2]. The effect of water ingress into the dam body by time has caused the bonding mortar to become more or less porous and high potential of water circulation. A conceptual proposal solution for rehabilitation of the Old Aswan Dam was presented by constructing a new layer of geomembrane on the upstream face of the Old Aswan dam [3]. Automatic detection of cracks is a necessary step in health monitoring of structures. A unique relationship was found to exist between the shrinkage rate and cracking time for the cement paste studied. The cracking time was expressed as a function of the relative humidity $(\mathrm{RH})$ drop rate and the aggregate content of a concrete mixture based on a relationship between mixture shrinkage and RH established previously. It was found that a high RH drop rate increases cracking potential. Concrete containing an aggregate content of 50\% or less is highly sensitive to cracking, and thus is crucial for the cracking potential of the outer layer of concrete exposed to the environment without appropriate curing [4]. Cracks on/in concrete structure often affect its appearance, load carrying capacity, water tightness and durability. Hence, from the viewpoint of maintenance, quantitative analysis of cracks, such as determination of their width, length and orientation, is very important. New robust automated images processing method of detecting cracks in surface images of concrete structures is developed [5]. In the future, concrete will be faced with the design of concrete with the most desirable shrinkage characteristics while still meeting strength requirements. Many concrete investigators believe creep and shrinkage are closely related. Shrinkage of concrete can be associated with changes in ambient humidity and differences in moisture conditions between the concrete and the environment. Shrinkage is generally an undesirable quality of concrete [6]. Comparatively rich mixes of high strength are needed in many cases. The increase of cement content due to the richness of the mix tends to increase drying shrinkage and thermal expansion and to decrease thermal diffusivity. It is also accompanied by an increase in the heat of hydration which makes it more likely to develop thermal and shrinkage cracking. In many cases methods to improve thermal properties and to control the temperature rise are not the same as those to improve drying shrinkage. Superplasticizers have considerable advantages over conventional plasticizers and in order to convince potential users of benefits to be gained, a series of tests has been undertaken to investigate the long-term behavior of concerts containing the super plasticizer [7]. Many reports have been published on various properties of superplasticizer admixed concrete, however, their volume change characteristics such as drying shrinkage, creep, and thermal movements have not been clarified sufficiently [8], [9], [10]. 


\section{Research Significance}

The effects of cement type, cement content and superplastisizer on concrete shrinkage characteristics are examined for rehabilitation of old dams. Three types of cement and three different cement contents are used for mixes with and without admixture. The results show that the increase of cement content tends to increase drying shrinkage by $35 \%-55 \%$ compared with concrete mixes with $350 \mathrm{~kg} / \mathrm{m}^{3}\left(590 \mathrm{Lb} / \mathrm{yd}^{3}\right)$ cement content. For Sulphate Resisting cement concrete mixes with $1 \%$ superplasticizer decreases shrinkage up to $38 \%$ compared with mixes without admixtures. Undesirable shrinkage may occur depending on excessive dosage of superplasticizer.

\section{Experimental Investigation}

Simplified method for analyzing service performance are justified because the prediction and control of time depended deformations and their effects on concrete structures are exceedingly complex when compared with the methods for analysis and design of strength performance [11]. Shrinkage of hardened concrete is influenced by various factors. The most important influence is exerted by the aggregate, which restrains the amount of shrinkage of cement paste that can actually be realized in the concrete [12].

\subsection{Materials}

The materials used are crushed pink lime stone, sand, Ordinary Portland cement (O.P.C.), Sulphate resistance cement (S.R.C.), Blast-Furnace Slag Cement (S.C.), potable water and one type of superplasticizer admixture type F (ASTM-C 494 type F) [13]. The superplasticizer is used to achieve a higher strength by decreasing the water cement ratio, achieve high early strength (after 8 hours) and to reduce permeability. Dosage of superplasticizer type $\mathrm{F}$ is from $1 \%$ and $2 \%$ of weight of cement and its specific gravity is $1.24 \mathrm{~kg} / \mathrm{liter}$ (2.5 Lb/liter). One nominal maximum size is used $3.75 \mathrm{~cm}$ (1.5 in) according to ASTM-C 33[14]. Each size of the coarse aggregate is added to the mixture by weight which fulfills the desired grading. The (ASTM-C 33 )[14], limits and the chosen grading of the coarse aggregate are shown in (Fig.1(a)). Coarse aggregate abrasion in the Lose-Angeles test is equal to 15\% According to (ASTM-C 131) [15]. The specific gravity and the dry bulk unit weight of the pink lime stone are equal to 2.6 and $1422 \mathrm{~kg} / \mathrm{m}^{3}\left(2379 \mathrm{Lb} / \mathrm{y}^{3}\right)$ respectively. It has absorption of $2.3 \%$. (Fig.1(b)) shows the grading of the used sand and the limits recommended for fine aggregate for concrete according to ( ASTM-C 33) [14], the specific gravity and dry bulk unit weight are equal to 2.3 and $1698 \mathrm{~kg} / \mathrm{m}^{3}\left(2863 \mathrm{Lb} / \mathrm{yd}^{3}\right)$ respectively. The fineness modulus is 2.4. (Fig. 2) shows the experimental program.

\subsection{Specimens}

According to (ASTM-C 157) [16], the Shrinkage test specimen for concrete is a prism with square section $75 \mathrm{~mm}$ (3 in) and $285 \mathrm{~mm}$ (11.25 in) long. Specimens of all mixes are stored in air and specimens of six mixes are stored in water for 28 days. The apparatus of shrinkage test is shown in (Fig. 3). The cylinder compressive strength test and the modulus of elasticity test are performed at 28 days. The shrinkage measurements are taken after 28 days. The dry shrinkage observations are taken at the age of 1 day. Design of concrete mixes is based on the absolute volume equation for one cubic meter according to concrete mixes suggested by (American concrete institute method) [17]. The proportions of concrete mixes are presented in Table 1 and Table 2. The relation between test time, relative humidity and temperature are presented in (Fig. 4) and (Fig. 5), respectively.

\section{Results And Discussion}

The results of all concrete mixes show that shrinkage increases with time. For O.P.C. concrete mixes without admixture using different cement content $350,400,450 \mathrm{~kg} / \mathrm{m}^{3}(590,675$ and.C. concrete mixes O1 without admixture, $\mathrm{O} 2$ with $1 \%$ admixture, and $\mathrm{O} 7$ with $2 \%$ admixture using the same $769 \mathrm{Lb} / \mathrm{yd}^{3}$ ) and a slump range $7.5-10 \mathrm{~cm}(3-4 \mathrm{in})$, the maximum shrinkage of mix with $350 \mathrm{~kg} / \mathrm{m}^{3}\left(590 \mathrm{Lb} / \mathrm{yd}^{3}\right)$ cement content is $45 \%$ less than that of mix with $450 \mathrm{~kg} / \mathrm{m}^{3}\left(769 \mathrm{Lb} / \mathrm{yd}^{3}\right)$ cement content (Fig. 6). For O.P cement content $350 \mathrm{~kg} / \mathrm{m}^{3}$ $\left(590 \mathrm{Lb} / \mathrm{yd}^{3}\right)$ and a slump range $7.5-10 \mathrm{~cm}(3-4 \mathrm{in})$, up to 45 days the mix with $2 \%$ admixture has the highest shrinkage and the mix without admixture has the lowest shrinkage, after 45 days the mix with $1 \%$ admixture has the highest shrinkage, and the mix with $2 \%$ admixture has the lowest shrinkage (Fig.7). The use of $2 \%$ superplasticizer has different effects on shrinkage with time compared with other mixes. According to (ACI committee 212) ${ }^{18}$, undesirable shrinkage may occur depending on excessive dosage of superplasticizer and chemical composition of the cement itself. For S.R.C. concrete mixes without admixture using different cement content 350,400 and $450 \mathrm{~kg} / \mathrm{m}^{3}\left(590,675\right.$ and $\left.769 \mathrm{Lb} / \mathrm{yd}^{3}\right)$ and a slump range $7.5-10 \mathrm{~cm}(3-4$ in) the maximum shrinkage of mix with $350 \mathrm{~kg} / \mathrm{m}^{3}\left(590 \mathrm{Lb} / \mathrm{yd}^{3}\right)$ cement content is $35 \%$ less than that of mix with $400 \mathrm{~kg} / \mathrm{m}^{3}(675$ $\mathrm{Lb} / \mathrm{yd}^{3}$ ) cement content (Fig. 8). For S.R.C. concrete mixes with and without admixture using the same cement 
content $350 \mathrm{~kg} / \mathrm{m}^{3}\left(590 \mathrm{Lb} / \mathrm{yd}^{3}\right)$ and a slump range $7.5-10 \mathrm{~cm}(3-4 \mathrm{in})$ shows that the mix without admixture has the highest shrinkage and the mix with $1 \%$ admixture has the lowest shrinkage (Fig.9). Compared with mix without admixture the use of $1 \%$ admixture reduced the maximum shrinkage by $37 \%$ while the use of $2 \%$ admixture reduced maximum shrinkage by $20 \%$. For S.C. concrete mixes without admixture, using different cement content 350,400 , and $450 \mathrm{~kg} / \mathrm{m}^{3}\left(590,675\right.$ and $\left.769 \mathrm{Lb} / \mathrm{yd}^{3}\right)$ shows that the maximum shrinkage of mix with $350 \mathrm{~kg} / \mathrm{m}^{3}\left(590 \mathrm{Lb} / \mathrm{yd}^{3}\right)$ cement content is $52 \%$ less than that of mix with $450 \mathrm{~kg} / \mathrm{m}^{3}\left(769 \mathrm{Lb} / \mathrm{yd}^{3}\right)$ cement content (Fig.10). For S.C. concrete mixes with $450 \mathrm{~kg} / \mathrm{m}^{3}\left(769 \mathrm{Lb} / \mathrm{yd}^{3}\right)$ cement content with and without admixture the use of admixture with the ratio of $1 \%$ result in decreasing shrinkage of concrete compared with concrete without admixture. The maximum Shrinkage of mix with $1 \%$ admixture is $65 \%$ less than that of mix without admixture (Fig.11).

\section{Conclusion And Recommendations}

A conceptual proposal for retrofitting Old dams such as the Old Aswan Dam in Egypt is by using a shrinkage-reduced concrete mix. For O.P.C., S.R.C. and S.C. concrete mixes, the increase of cement content from $350 \mathrm{~kg} / \mathrm{m}^{3}\left(590 \mathrm{Lb} / \mathrm{yd}^{3}\right)$ up to $450 \mathrm{~kg} / \mathrm{m}^{3}\left(769 \mathrm{Lb} / \mathrm{yd}^{3}\right)$ tends to increase drying shrinkage $35 \%$ up to $55 \%$. Based on the results of the current study, the increase of cement content due to the richness of the mix tends to increase drying shrinkage. For concrete mixes with slump range 7.5-10 cm (3-4 in), the use of the super plasticizer with the ratio of $1 \%$ results in decreasing the water cement ratio by $5.5 \%$, up to $20 \%$ and the use of super plasticizer with the ratio of $2 \%$ results in decreasing the water cement ratio by $19 \%$, up to $38 \%$. For S.R.C. concrete mixes with $350 \mathrm{~kg} / \mathrm{m}^{3}\left(590 \mathrm{lb} / \mathrm{yd}^{3}\right)$ cement compared with mix without admixture the use of $1 \%$ admixture reduced the maximum shrinkage by $37 \%$ while the use of $2 \%$ admixture reduced maximum shrinkage by $20 \%$. For S.C. concrete mixes with $450 \mathrm{~kg} / \mathrm{m} 3\left(769 \mathrm{lb} / \mathrm{yd}^{3}\right)$ cement content the use of $1 \%$ admixture results in decreasing shrinkage of concrete by $65 \%$ compared with mix without admixture. Undesirable shrinkage may occur depending on excessive dosage of superplasticizer and chemical composition of the cement itself. These results agree with ACI committee 212 [18]. The pink lime stone concrete mix with $350 \mathrm{~kg} / \mathrm{m}^{3}\left(590 \mathrm{lb} / \mathrm{yd}^{3}\right)$ sulfate resistance cement content and $1 \%$ superplasticizer admixture has acceptable shrinkage for rehabilitation concepts of old dams such as the Old Aswan dam; compared with the achieved results of the used mixes. It is recommended to study the effect of other dosage of admixtures and different types of coarse aggregate to improve shrinkage for concrete mixes used in huge structures such as dams.

\section{Acknowledgments}

The author would like to express her gratitude to professor doctor Abd El-Wahab Awad -Structural Department, Faculty of Engineering, Alexandria University, for his helpful guides .

\section{References}

[1] Ministry of Irrigation, High and Aswan Dams Authority, Request for technical proposal seismic stability evaluation of the Old Aswan Dam, Aswan, July 1986

[2] Zaki, H., "Heightening of the Aswan Dam, Sixieme Congres Des Grands Barrages, New York, 1958

[3] El-Hifnawy, L., Abdelmohsen, H., Elkordi, E., Abdelfatah, S., Hydrodynamic water pressure for the Old Aswan Dam with impervious upstream face, International Conference on Earthquake Geotechnical Engineering, June 2013, Istanbul, Turkey, Boğaziçi University

[4] Wei, Y., and Hansen, W., Characterizing cracking potential of cementations' mixtures based on shrinkage and humidity drop rate, Materials Journal, 110-M39, 2013

[5] Nishikawa, T., Yashikawa, J., and Fujino, Y., Concrete crack detection by multiple sequential image filtering, Computer-Aided Civil and Infrastructure Engineering 27, 2012

[6] Therese M., and Collins, Proportioning high-strength concrete to control creep and shrinkage, ACI Materials Journal Title No. 86-M55, 1989

[7] Brooks, J., J., Wainwright, P., J., and Neville A., M., Time-dependent properties of concrete containing a super plasticizing admixture, ACI Publication SP 62-15, 1979

[8] Tokuda, H., Shoya, M., Kawakami, M., and Kagaya, M., "Application Of Superplasticizer To Reduce Drying Shrinkage And Thermal Cracking Of Concrete," ACI Publication SP 68-6, 1981

[9] Salah, A., a., and David A. Lange , Creep, shrinkage, and cracking of restrained concrete at early age, Materials Journal 98-M35, 2001

[10] Soliman, A., M., and Nehdi, M., L., Self-restraining shrinkage ultra-high-performance concrete: mechanisms and evidence, Materials Journal, 110, 4, 2013

[11] ACI (1992) Prediction of creep, shrinkage and temperature effects in concrete structures. Report ACI209R-82. American Concrete Institute Committee 209, Detroit

[12] Neville, A., M., and Brooks, J., J., Concrete Technology 1987 
[13] ASTM-C 494 Standard specification for chemical admixtures for concrete

[14] ASTM-C 33 Standard specification for concrete aggregates

[15] ASTM-C 131 Standard test method for resistance to degradation of small-size coarse aggregate by abrasion and impact in the Los Angeles machine

[16] ASTM-C 157 Standard test method for length change of hardened cement mortar and concrete

[17] ACI Committee 211R-85 Standard practice for selecting proportions for normal, heavy weight and mass concrete. Part 1: Materials and general properties of concrete. ACI Manual of concrete practice. American Concrete Institute, Detroit

[18] ACI Committee 212.1R-81 Admixtures for concrete. Part 1: Materials and general properties of concrete. ACI Manual of concrete practice. American Concrete Institute, Detroit

\section{List of Tables:}

\section{TABLES AND FIGURES}

Table 1 - Proportions of the Ordinary Portland cement (O. P. C) concrete mixes

Table 2 - Proportions of Sulphate Resistance cement (S.R.C.) and Slag cement (S.C.) concrete mixes

\section{List of Figures:}

Fig. 1 - Grading curve of used gravel

Fig. 2 - Experimental Program

Fig. 3 - Shrinkage apparatus

Fig. 4- Relation between test time (days) and relative humidity-percent

Fig. 5 Relation between test time (days) and temperature

Fig. 6 - Shrinkage of Ordinary Portland cement concrete mixes without admixture using 350,400, $450 \mathrm{~kg} / \mathrm{m}^{3}\left(590,675,769 \mathrm{Lb} / \mathrm{yd}^{3}\right)$ cement content

Fig. 7- Shrinkage of Ordinary Portland cement concrete mixes cement content $350 \mathrm{~kg} / \mathrm{m}^{3}(590$ $\mathrm{Lb} / \mathrm{yd}^{3}$ ) with and without admixture

Fig.8- Shrinkage Sulphate Resisting cement concrete mixes using 350,400, $450 \mathrm{~kg} / \mathrm{m}^{3}$ (590, 675, $769 \mathrm{Lb} / \mathrm{yd}^{3}$ ) cement content without admixture

Fig. 9- Shrinkage Sulphate Resisting cement concrete mixes using $350 \mathrm{~kg} / \mathrm{m}^{3}\left(590 \mathrm{Lb} / \mathrm{yd}^{3}\right)$ cement content with and without admixture admixture

Fig.10- Shrinkage Slag cement concrete mixes using 350,400, $450 \mathrm{~kg} / \mathrm{m}^{3}\left(590,675,769 \mathrm{Lb} / \mathrm{yd}^{3}\right)$ cement content without admixture

Fig. 11- Shrinkage of Slag cement concrete mixes using $450 \mathrm{~kg} / \mathrm{m}^{3}\left(769 \mathrm{Lb} / \mathrm{yd}^{3}\right)$ cement content with and without admixture admixture

Table 1 -Proportions of the Ordinary Portland cement (O. P. C) concrete mixes (- Lb- pound)

\begin{tabular}{|c|c|c|c|c|c|c|c|}
\hline Parameters & \multicolumn{7}{|c|}{ MIXES } \\
\hline $\begin{array}{l}\text { Type of } \\
\text { cement }\end{array}$ & \multicolumn{7}{|c|}{ O.P.C } \\
\hline MIX. & $\mathrm{O} 1$ & $\mathrm{O} 2$ & $\mathrm{O} 3$ & $\mathrm{O} 4$ & $\mathrm{O} 5$ & O6 & $\mathrm{O} 7$ \\
\hline $\begin{array}{c}\text { Wt. of cement } \\
\mathrm{kg} / \mathrm{m}^{3} \\
\left(\mathrm{Lb} / \mathrm{yd}^{3}\right)\end{array}$ & $\begin{array}{c}350 \\
(590)\end{array}$ & $\begin{array}{c}350 \\
(590)\end{array}$ & $\begin{array}{c}400 \\
(675)\end{array}$ & $\begin{array}{c}400 \\
(675)\end{array}$ & $\begin{array}{c}450 \\
(769)\end{array}$ & $\begin{array}{c}450 \\
(769)\end{array}$ & $\begin{array}{c}350 \\
(590)\end{array}$ \\
\hline $\begin{array}{l}\text { Wt. of course } \\
\text { agg. } \mathrm{kg} / \mathrm{m}^{3} \\
\left(\mathrm{Lb} / \mathrm{yd}^{3}\right)\end{array}$ & $\begin{array}{c}1067 \\
(1799)\end{array}$ & $\begin{array}{c}1067 \\
(1799)\end{array}$ & $\begin{array}{c}1067 \\
(1799)\end{array}$ & $\begin{array}{c}1067 \\
(1799)\end{array}$ & $\begin{array}{c}1067 \\
(1799)\end{array}$ & $\begin{array}{c}1067 \\
(1799)\end{array}$ & $\begin{array}{c}1067 \\
(1799)\end{array}$ \\
\hline $\begin{array}{c}\text { Wt. of water } \\
\mathrm{kg} / \mathrm{m}^{3} \\
\left(\mathrm{Lb} / \mathrm{yd}^{3}\right)\end{array}$ & $\begin{array}{l}184.5 \\
(311)\end{array}$ & $\begin{array}{c}160.5 \\
(270.6\end{array}$ & $\begin{array}{l}209.5 \\
(353)\end{array}$ & $\begin{array}{l}177.5 \\
(299)\end{array}$ & $\begin{array}{c}223.5 \\
(276.8)\end{array}$ & $\begin{array}{c}182.5 \\
(3305)\end{array}$ & $\begin{array}{c}150 \\
(253)\end{array}$ \\
\hline $\begin{array}{c}\text { Wt. Of sand } \\
\mathrm{kg} / \mathrm{m} 3 \\
\left(\mathrm{Lb} / \mathrm{yd}^{3}\right)\end{array}$ & $\begin{array}{c}687 \\
(1158)\end{array}$ & $\begin{array}{c}742 \\
(1251)\end{array}$ & $\begin{array}{c}580 \\
(978)\end{array}$ & $\begin{array}{c}655 \\
(1104)\end{array}$ & $\begin{array}{c}503 \\
(848)\end{array}$ & $\begin{array}{c}600 \\
(1012)\end{array}$ & $\begin{array}{c}720 \\
(1214)\end{array}$ \\
\hline
\end{tabular}




\begin{tabular}{|c|c|c|c|c|c|c|c|}
\hline $\begin{array}{c}\text { Wt. of adm. } \\
\mathrm{kg} / \mathrm{m}^{3} \\
\left(\mathrm{Lb} / \mathrm{yd}^{3}\right) \\
(\mathrm{Lb}=\text { pound- } \\
\text { =yard })\end{array}$ & $\begin{array}{c}0 \\
(0)\end{array}$ & $\begin{array}{c}3.5 \\
(5.9)\end{array}$ & $\begin{array}{c}0 \\
(0)\end{array}$ & $\begin{array}{c}4 \\
(6.74)\end{array}$ & $\begin{array}{c}0 \\
(0)\end{array}$ & $\begin{array}{c}4.5 \\
(7.6)\end{array}$ & $\begin{array}{c}7 \\
(11.8)\end{array}$ \\
\hline $\begin{array}{c}\text { Slump cm } \\
\text { (in) }\end{array}$ & & \multicolumn{6}{|c|}{$\begin{array}{c}7.5-10 \\
(3-4)\end{array}$} \\
\hline W/c & 0.53 & 0.46 & 0.52 & 0.44 & 0.5 & 0.41 & 0.43 \\
\hline Agg./ cement & 5 & 5.17 & 4.12 & 4.3 & 4.49 & 3.7 & 5.1 \\
\hline
\end{tabular}

Table 2 -Proportions of Sulphate Resistance cement (S.R.C.) and Slag cement (S.C.) concrete mixes

\begin{tabular}{|c|c|c|c|c|c|c|c|c|c|c|c|c|c|}
\hline Parameters & \multicolumn{13}{|c|}{ MIXES } \\
\hline $\begin{array}{l}\text { Type of } \\
\text { cement }\end{array}$ & \multicolumn{7}{|c|}{ SULPHATE R.C } & \multicolumn{6}{|c|}{ SLAG C. } \\
\hline MIX. & R1 & R2 & R3 & R4 & R5 & R6 & R7 & S1 & S2 & S3 & S4 & S5 & S6 \\
\hline $\begin{array}{l}\text { Wt. of cement } \\
\mathrm{kg} / \mathrm{m}^{3} \\
\left(\mathrm{Lb} / \mathrm{yd}^{3}\right)\end{array}$ & $\begin{array}{l}350 \\
(59\end{array}$ & $\begin{array}{l}350 \\
(59\end{array}$ & $\begin{array}{l}400 \\
(67\end{array}$ & $\begin{array}{l}400 \\
(67\end{array}$ & $\begin{array}{l}450 \\
(769\end{array}$ & $\begin{array}{l}450 \\
(76\end{array}$ & $\begin{array}{c}350 \\
(590)\end{array}$ & $\begin{array}{c}350 \\
(590)\end{array}$ & $\begin{array}{c}350 \\
(590)\end{array}$ & $\begin{array}{c}400 \\
(675)\end{array}$ & $\begin{array}{c}400 \\
(675)\end{array}$ & $\begin{array}{c}450 \\
(769)\end{array}$ & $\begin{array}{c}450 \\
(769)\end{array}$ \\
\hline $\begin{array}{l}\text { Wt. of course } \\
\text { agg. } \mathrm{kg} / \mathrm{m}^{3} \\
\left(\mathrm{Lb} / \mathrm{yd}^{3}\right)\end{array}$ & $\begin{array}{l}106 \\
(17\end{array}$ & $\begin{array}{l}106 \\
(17\end{array}$ & $\begin{array}{l}106 \\
(17\end{array}$ & $\begin{array}{l}106 \\
(17\end{array}$ & $\begin{array}{l}1067 \\
(179\end{array}$ & $\begin{array}{l}1067 \\
(179\end{array}$ & $\begin{array}{l}1067 \\
(1799\end{array}$ & $\begin{array}{c}1067 \\
(1799)\end{array}$ & $\begin{array}{c}1067 \\
(1799)\end{array}$ & $\begin{array}{c}1067 \\
(1799)\end{array}$ & $\begin{array}{c}1067 \\
(1799)\end{array}$ & $\begin{array}{c}1067 \\
(1799)\end{array}$ & $\begin{array}{c}1067 \\
(1799)\end{array}$ \\
\hline $\begin{array}{l}\text { Wt. of water } \\
\mathrm{kg} / \mathrm{m}^{3} \\
\left(\mathrm{Lb} / \mathrm{yd}^{3}\right)\end{array}$ & $\begin{array}{l}184 \\
(31\end{array}$ & $\begin{array}{l}168 . \\
(28\end{array}$ & $\begin{array}{l}209 . \\
(35\end{array}$ & $\begin{array}{l}178 \\
(30\end{array}$ & $\begin{array}{l}223 . \\
(376\end{array}$ & $\begin{array}{l}182 \\
(30\end{array}$ & $\begin{array}{c}150 \\
(253)\end{array}$ & $\begin{array}{c}189.5 \\
(319.5)\end{array}$ & \begin{tabular}{|l|}
170.5 \\
$(287)$
\end{tabular} & $\begin{array}{l}209.5 \\
(353)\end{array}$ & $\begin{array}{c}178 \\
(300)\end{array}$ & $\begin{array}{c}223.5 \\
(376.8)\end{array}$ & $\begin{array}{r}182.5 \\
(307.7)\end{array}$ \\
\hline $\begin{array}{c}\text { Wt. of sand } \\
\mathrm{kg} / \mathrm{m} 3 \\
\left(\mathrm{Lb} / \mathrm{yd}^{3}\right)\end{array}$ & $\begin{array}{l}687 \\
(11\end{array}$ & $\begin{array}{l}721 \\
(12\end{array}$ & $\begin{array}{l}580 \\
(97\end{array}$ & $\begin{array}{l}655 \\
(11\end{array}$ & $\begin{array}{l}503 \\
(848\end{array}$ & $\begin{array}{l}600 \\
(10\end{array}$ & $\begin{array}{c}720 \\
(1214\end{array}$ & $\begin{array}{c}673 \\
(1135)\end{array}$ & $\begin{array}{c}716 \\
(1207)\end{array}$ & $\begin{array}{c}580 \\
(978)\end{array}$ & $\begin{array}{c}655 \\
(1104)\end{array}$ & $\begin{array}{c}503 \\
(848)\end{array}$ & $\begin{array}{c}600 \\
(1012)\end{array}$ \\
\hline $\begin{array}{c}\text { Wt. of adm. } \\
\mathrm{kg} / \mathrm{m}^{3} \\
\left(\mathrm{Lb} / \mathrm{yd}^{3}\right) \\
(\mathrm{Lb}=\text { pound } \\
\text { yd =yard) }\end{array}$ & $\begin{array}{c}0 \\
(0)\end{array}$ & $\begin{array}{l}3.5 \\
5.9\end{array}$ & $\begin{array}{c}0 \\
(0)\end{array}$ & $\begin{array}{c}4 \\
(6.7\end{array}$ & $\begin{array}{c}0 \\
(0)\end{array}$ & $\begin{array}{l}4.5 \\
(7.6\end{array}$ & $\begin{array}{c}7 \\
(11.8)\end{array}$ & $\begin{array}{c}0 \\
(0)\end{array}$ & $\begin{array}{c}3.5 \\
(5.9)\end{array}$ & $\begin{array}{c}0 \\
(0)\end{array}$ & $\begin{array}{c}4 \\
(6.74)\end{array}$ & $\begin{array}{c}0 \\
(0)\end{array}$ & $\begin{array}{c}4.5 \\
(7.6)\end{array}$ \\
\hline$\underset{\text { (in) }}{\text { Slump }} \mathrm{cm}$ & \multicolumn{7}{|c|}{$\begin{array}{c}7.5-10 \\
(3-4)\end{array}$} & \multicolumn{6}{|c|}{$\begin{array}{c}7.5-10 \\
(3-4)\end{array}$} \\
\hline $\mathrm{w} / \mathrm{c}$ & 0.53 & 0.48 & 0.52 & 0.44 & 0.5 & 0.4 & 0.43 & 0.54 & 0.49 & 0.52 & 0.44 & 0.5 & 0.41 \\
\hline Agg / cement & 5.0 & 5.11 & 4.12 & 4.31 & 3.49 & 3.7 & 5.1 & 4.97 & 5.09 & 4.12 & 4.31 & 3.4 & $3.7 \mathrm{~A}$ \\
\hline
\end{tabular}
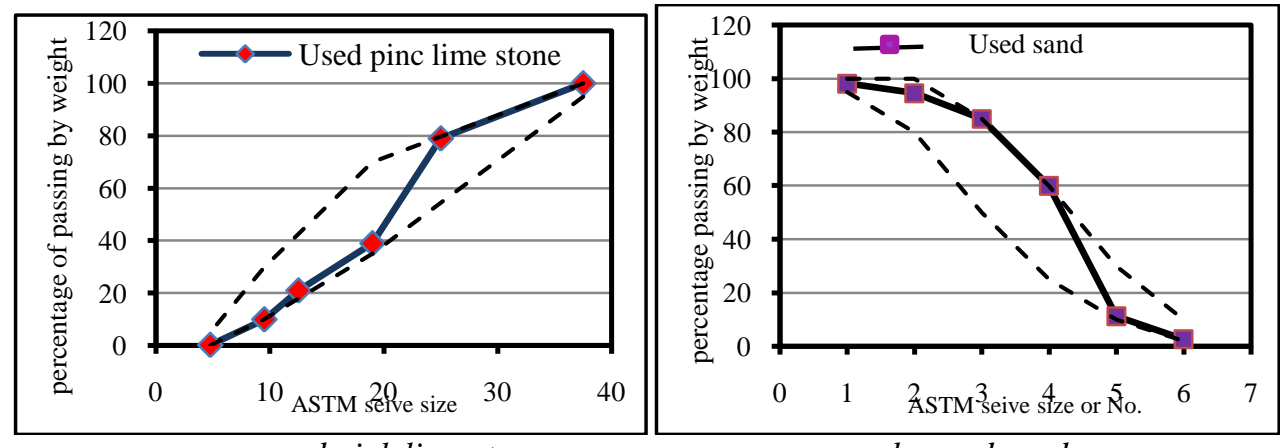

a- used pink lime stone

$b$ - used sand

Fig. 1- Grading curve of used gravel 


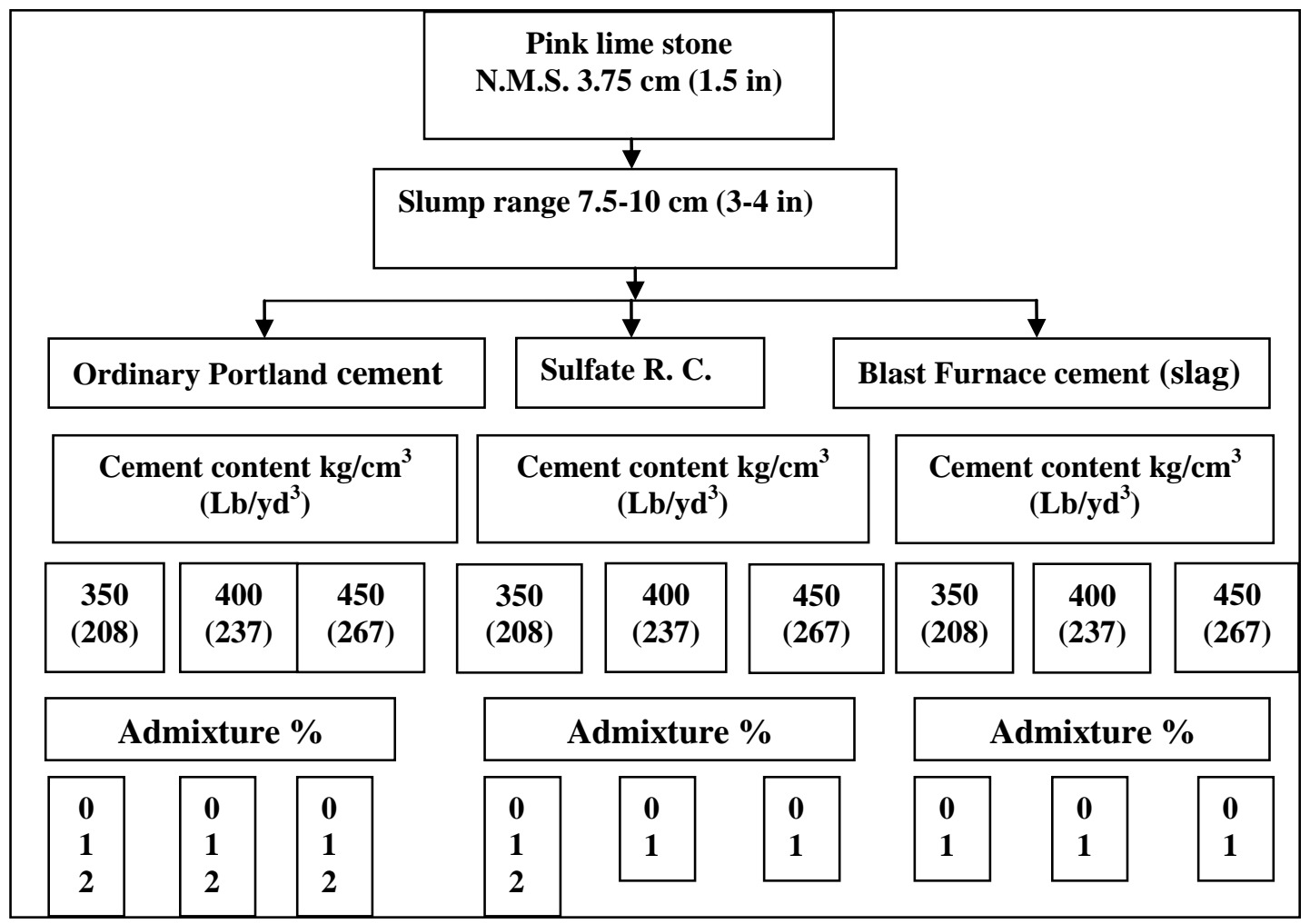

Fig. 2- Experimental Program
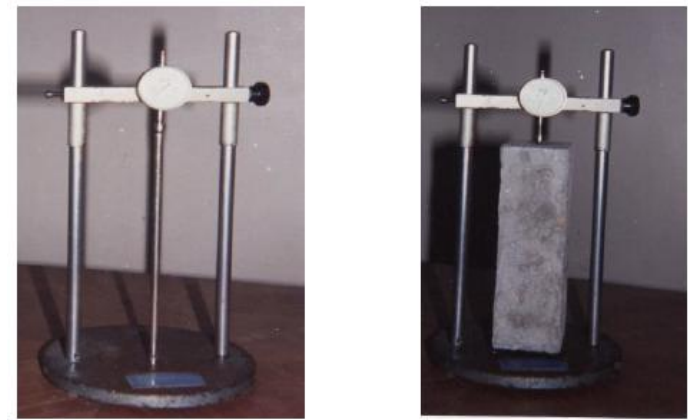

Fig. 3 - Shrinkage apparatus

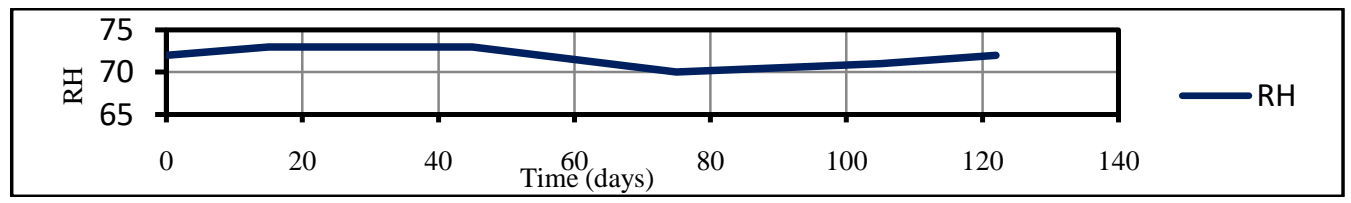

Fig. 4- Relation between test time (days) and relative humidity-percent

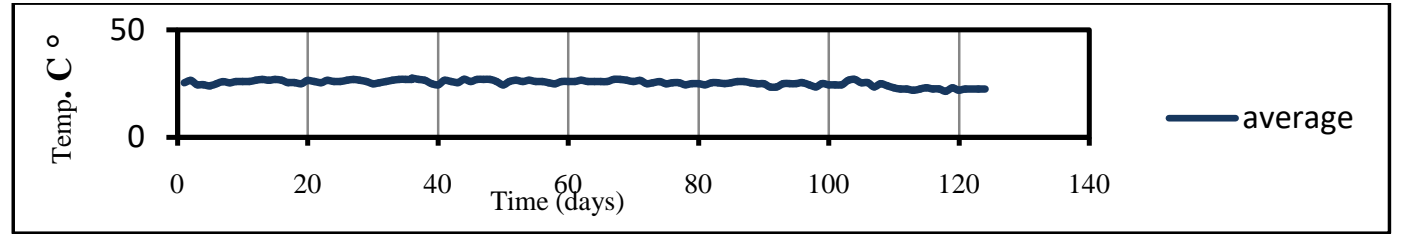

Fig. 5- Relation between test time (days) and temperature $\left(\mathrm{F}=1.8 \mathrm{C}^{\mathbf{0}}+32\right)$ 


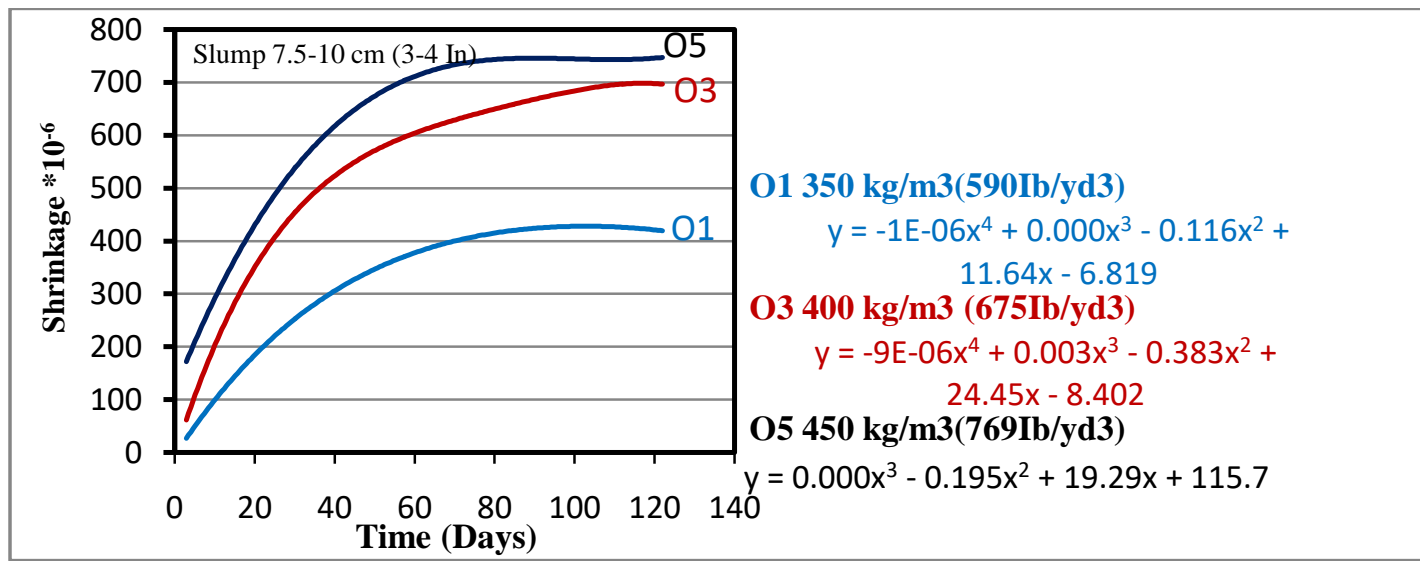

Fig. 6- Shrinkage of Ordinary Portland cement concrete mixes without admixture using $350,400,450 \mathrm{~kg} / \mathrm{m}^{3}\left(590,675,769 \mathrm{Lb} / \mathrm{yd}^{3}\right)$ cement content

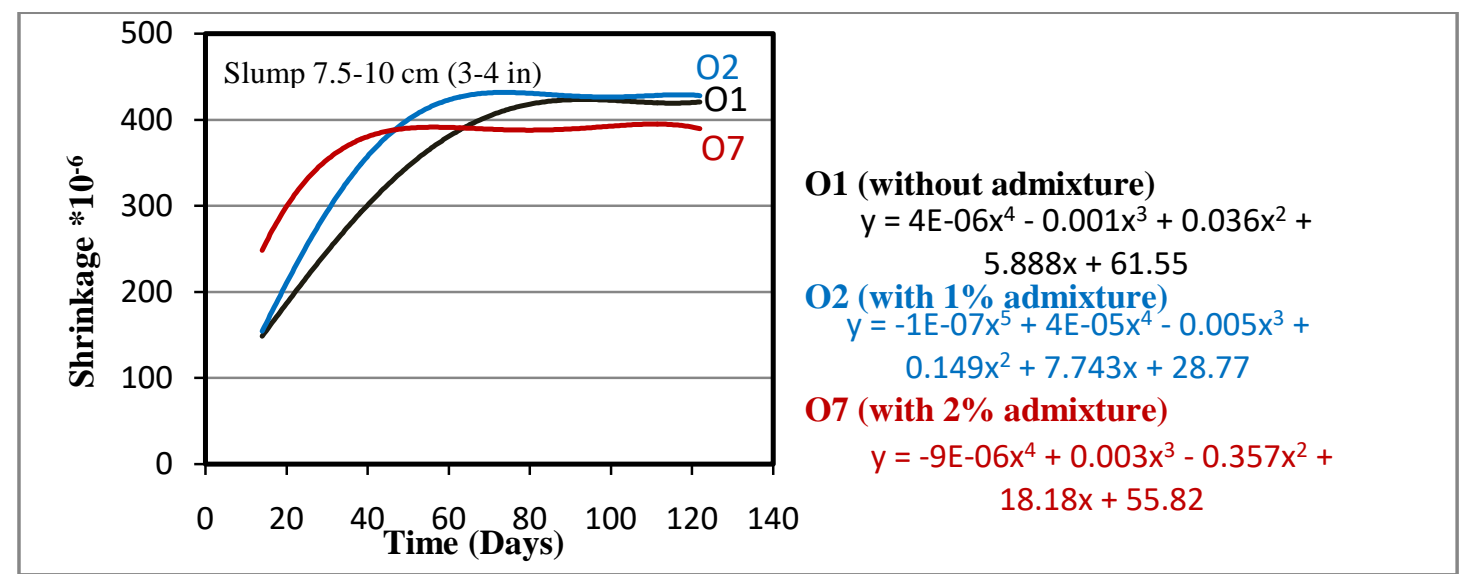

Fig. 7- Shrinkage of Ordinary Portland cement concrete mixes cement content $350 \mathrm{~kg} / \mathrm{m}^{3}$ $\left(590 \mathrm{Lb} / \mathrm{yd}^{3}\right)$ with and without admixture

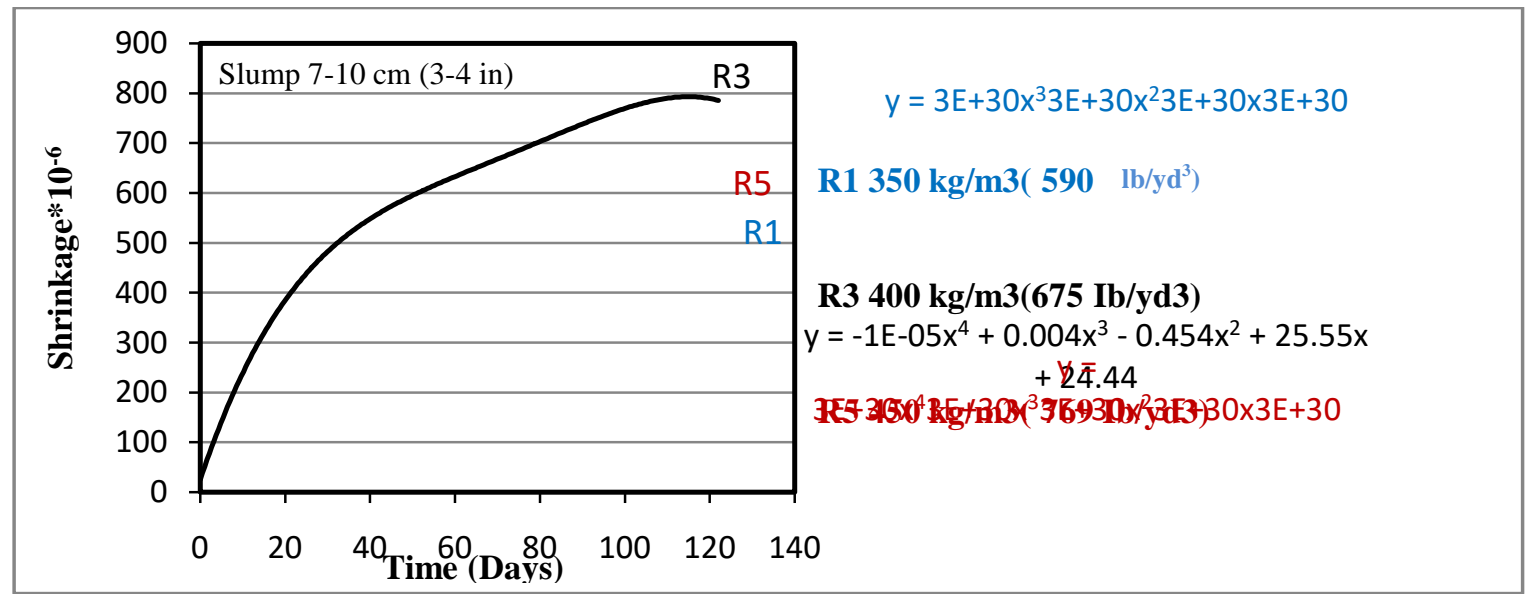

Fig. 8- Shrinkage Sulphate Resisting cement concrete mixes using 350,400, $450 \mathrm{~kg} / \mathrm{m}^{3}(590,675$, $\left.769 \mathrm{Lb} / \mathrm{yd}^{3}\right)$ cement content without admixture 


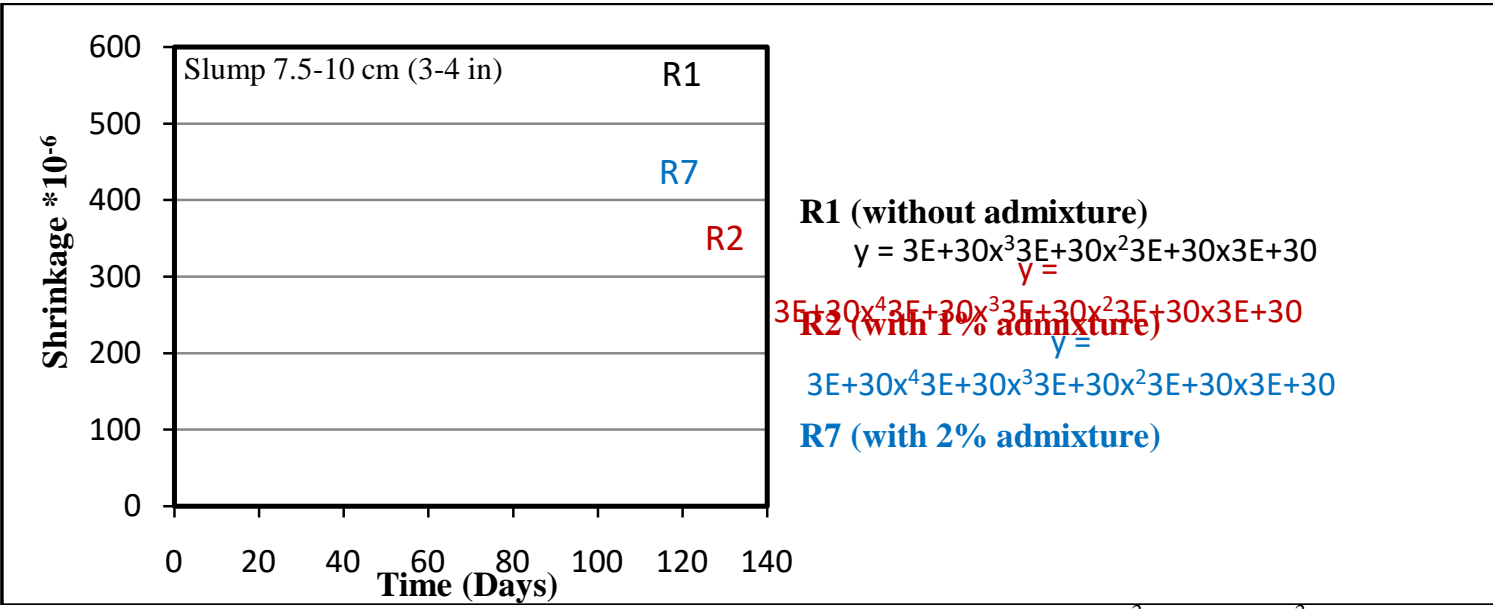

Fig. 9- Shrinkage Sulphate Resisting Cement concrete mixes using $350 \mathrm{~kg} / \mathrm{m}^{3}\left(590 \mathrm{Lb} / \mathrm{yd}^{3}\right)$ Cement content with and without admixture admixture

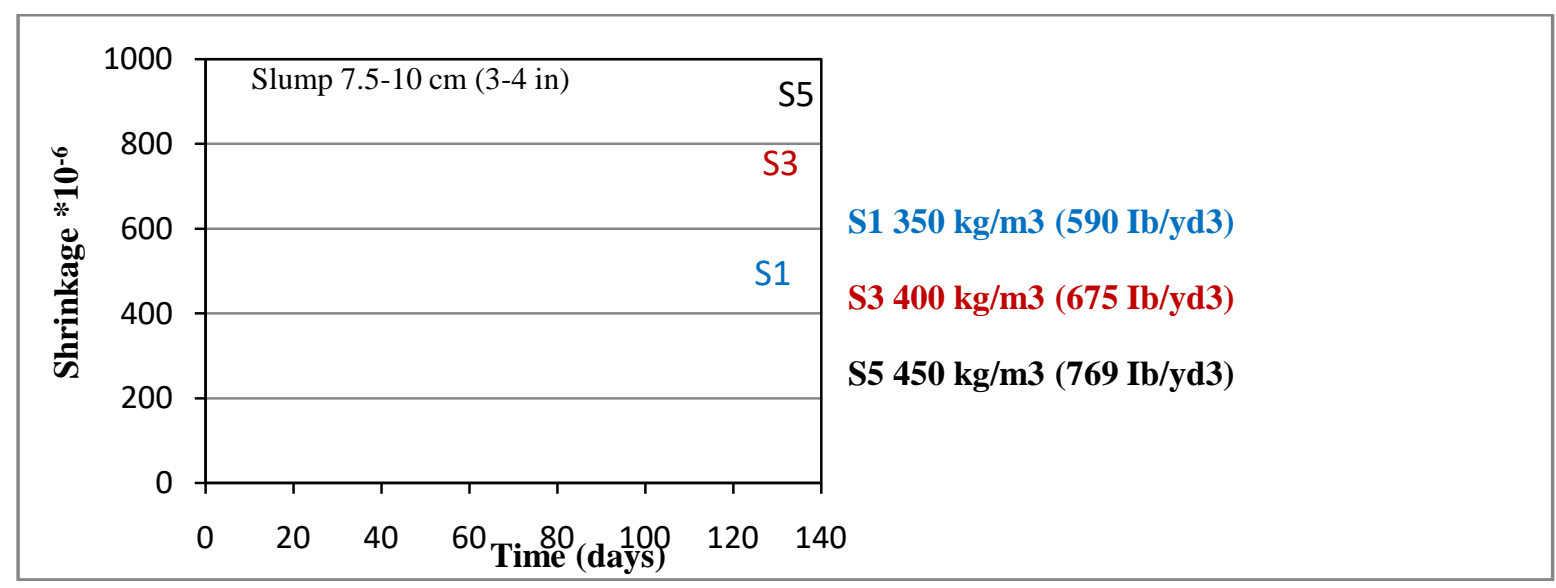

Fig. 10- Shrinkage of Slag cement concrete mixes using $350,400,450 \mathrm{~kg} / \mathrm{m}^{3}\left(590,675,769 \mathrm{Lb} / \mathrm{yd}^{3}\right)$ cement content without admixture

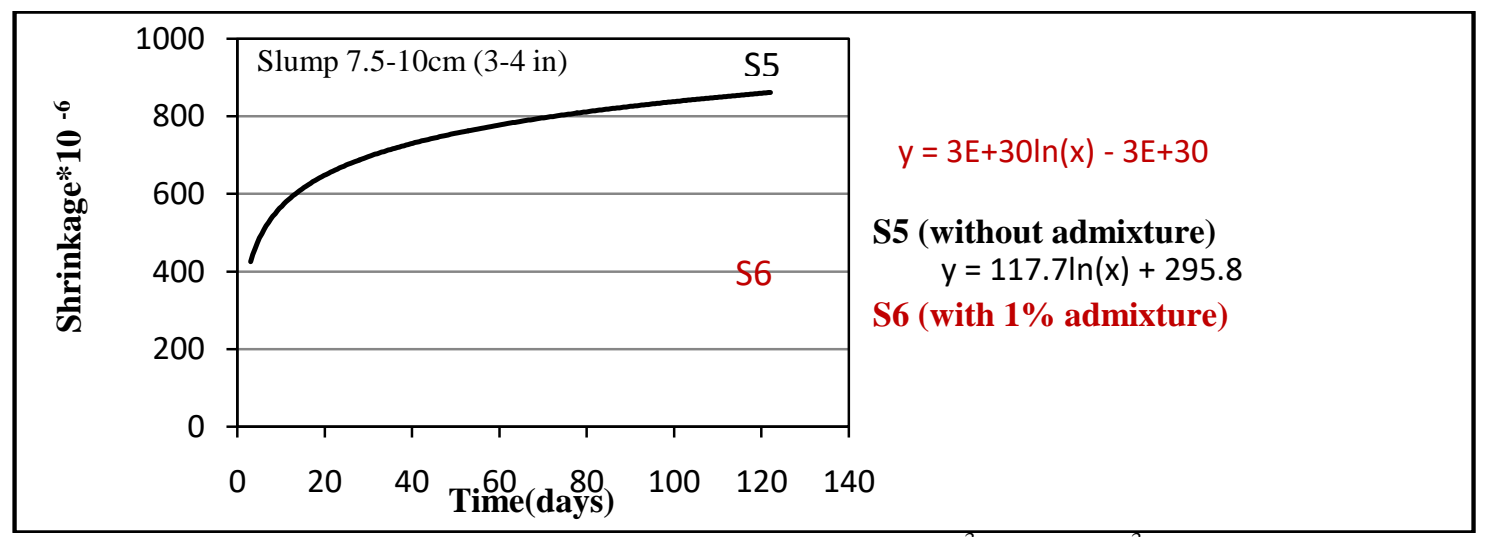

Fig. 11- Shrinkage of Slag cement concrete mixes using $450 \mathrm{~kg} / \mathrm{m}^{3}\left(769 \mathrm{Lb} / \mathrm{yd}^{3}\right)$ cement content with and without admixture admixture 